\title{
9. Did the 1981 Budget refute naïve Keynesianism?
}

The 1981 Budget was undoubtedly a turning point in British macroeconomic policy-making. It stimulated a sharp controversy about the role of fiscal policy in economic management, with 364 economists writing a letter to The Times in protest against the raising of $£ 4$ billion extra taxes (about 2 per cent of gross domestic product) in a recession. They warned that 'present policies will deepen the depression', and 'threaten ... social and political stability'. It is fair to say, first, that the overwhelming majority of British academic economists disapproved of the 1981 Budget and, secondly, that they were quite wrong in their prognoses of its consequences. This essay discusses some of the issues in economic theory which it raised.

\section{I}

Until the 1930s the dominant doctrine in British public finance was that the budget should be balanced. Keynes challenged this doctrine, with many authorities citing his classic work - The General Theory of Employment, Interest and Money - as the rationale for discretionary fiscal policy (that is, the deliberate unbalancing of the budget, with deficits in recessions and surpluses in booms). In fact, the remarks on fiscal policy in The General Theory were perfunctory. The case for discretionary fiscal policy was made more explicitly in two articles on 'Paying for the war' in The Times on 14 and 15 November 1939. ${ }^{1}$ These articles were a response to an unusual and very specific macroeconomic problem, the need to switch resources from peacetime uses to wartime production, but their influence was long-lasting. They assumed an approach to macroeconomic analysis, in which - given the present level of incomes - the sum of potential expenditures could be compared with the value of output at current prices. If potential expenditures exceeded the value of output, inflation was likely. In the 1939 articles Keynes noted that equilibrium could be restored by 'three genuine ways' and 'two pseudo-remedies'. After rejecting the pseudo-remedies (rationing and anti-profiteering), Keynes focused on the three 'genuine' answers - inflation, taxation and deferred savings. He opposed inflation, 
and recommended taxation and deferred savings to eliminate excess demand.

Over time Keynes's analysis had a powerful effect on official thinking. In a book published in 1982 Ball referred to 'the almost total acceptance of Keynesian prescriptions by economists, public servants and politicians of both left and right in the United Kingdom'. ${ }^{2}$ The remarks in the two articles in The Times were elaborated in a theory of national income determination which took hold in the textbooks of the 1950s and 1960s. Quoting from Dow (from a book on Major Recessions published in 1998),

Interpretation of events cannot depend on unstructured observation, but has to be based on assumptions ... about the causal structure of the economy ... . Total demand is defined in terms of real final expenditure; its level (in the absence of shocks) is determined by previous income; its result is output, in the course of producing which income is generated; income in turn goes to determine demand in the subsequent period. ${ }^{3}$

In short, income determines expenditures which determine income and output which determines expenditures which determine income and output so on, as if in a never-ending circle. The circular flow of incomes and expenditure is conceived here as being between passive private sector agents with no way of adding to or subtracting from incomes from one period to the next, and without the inclination to vary the proportion of incomes that are spent. According to Dow's statement, the flow of private sector expenditures would proceed indefinitely at the same level, were it not for 'shocks'.

However, the textbooks did allow for additions to or subtractions from the circular flow by an active, well-intentioned and appropriately advised government. If the state itself spent above or beneath its tax revenue (if, in other words, it ran a budget deficit or surplus), it could add to or subtract from the circular flow. ${ }^{4}$ The notion of a circular flow of income, and the related idea of the income-expenditure model of the economy (which was adopted in econometric forecasting in the late 1960s and 1970s), therefore made fiscal policy the favourite weapon in the macroeconomic armoury. If all went well, the fiscal additions to and subtractions from the circular flow could be designed to keep the economy at full employment with price stability (or, at any rate, acceptably low inflation). The official judgement on the size of these additions and subtractions, announced with accompanying political theatre every year in the Budget, was taken to be of great significance. For economists brought up to believe that the incomeexpenditure model was an accurate description of 'how the economy worked' (and that included probably over 90 per cent of the UK's university economists at the time), the 1981 Budget was shockingly inept. They 
saw it as withdrawing demand in any economy where expenditure was weak and unemployment rising, and so as being totally misguided.

The circular flow of income is a useful teaching aid and is understandably popular in university macroeconomics courses. However, it is a primitive and incomplete account of national income determination. If this is 'Keynesianism', it is 'naïve Keynesianism'. Substantial amendments are needed to bring the story closer to the truth - and indeed to the authentic Keynes of the major works.

At the level of the individual private sector agent, it is incorrect that income and expenditure are the same in every period for two reasons. The first is simple. As agents hold money balances, they can spend above income in any given period by running down these balances. (Of course, if they spend beneath income, they add to their money holdings.) The second is more troublesome. The motive of Keynesian analysis is to determine national expenditure and income, in order to fix the level of employment. So the relevant 'expenditures' are those which lead to output in the current period and so necessitate employment. It is evident that expenditure on existing assets - such as houses that were built decades ago, ships after they have been launched, antiques inherited from previous generations and so on - does not result in more employment. (They have been made in past periods and do not need to be made again.) But purchases and sales of assets, and of financial securities which establish claims to assets, are on an enormous scale. As with money, an individual agent can spend above income in any given period by selling an asset and spending the proceeds, or spend beneath income by purchasing an asset out of savings from current income. Goods can be bought with money arising from the sale of assets and assets can be bought with money arising from the sale of goods.

At the aggregate level, the situation becomes even more complicated. Suppose, to ease the exposition, that an economy has no assets. If the amount of money is given for the economy as a whole, decisions by individual agents to run down or build up their money balances cannot alter the aggregate amount of money. However, even in this asset-less economy the amount of spending can vary between periods if the velocity of circulation of money changes. Of course, if the amount of money increases or declines from one period to the next, that also allows the level of expenditures to change with the velocity of circulation constant. ${ }^{5}$

Now remove the assumption of an asset-less economy. Money is used in two types of transaction. The first type relates to current expenditure (that is, 'aggregate demand'), output and employment, and belongs to the circular flow; the second type relates to expenditure on existing assets. This second type leads to asset re-dispositions and, typically, to changes in asset 
ownership. Total transactions consist of both transactions in the circular flow and transactions in assets. It should be noted that this distinction is not new. In fact, it was made by Keynes in his Treatise on Money, which was published in 1930 before The General Theory. To adopt his terms, 'deposits' (money, in other words) were used partly in 'industry' and partly in 'finance'. The 'industrial circulation' was concerned with 'maintaining the normal process of current output, distribution and exchange, and paying the factors of production their incomes'; the 'financial circulation', on the other hand, was involved with 'holding and exchanging existing titles to wealth, including stock exchange and money market transactions' and even 'speculation'. ${ }^{6}$ (Of course in the real world the same sum of money may be used in a transaction in goods one day and a transaction in assets the next. Money circulates endlessly. The distinction between the industrial and financial circulations - like any distinction relating to something as fluid as money - is to that degree artificial.)

How are these ideas to be put to analytical use? It is immediately clear that, with the quantity of money given, the value of aggregate demand can change for two reasons. First, money's velocity of circulation in total transactions may alter, with the relative size of Keynes' industrial and financial circulations constant. Secondly, the velocity of circulation of money in total transactions may stay the same, but the relative size of the industrial and financial circulations changes. It should be unnecessary to add that, if the quantity of money increases or decreases between periods, that introduces yet another potential source of disturbance.

In short, once the economy is allowed to have money and assets, the idea of a simple period-after-period equivalence of income and expenditure becomes implausible. The circular flow of income and expenditure would remain a valid description of the economy if the following were constant:

1. The quantity of money,

2. The velocity of money in total transactions, and

3. The proportion of transactions in the circular flow to total transactions (or, in Keynes's terminology in The Treatise on Money, the ratio between the industrial circulation and the industrial and financial circulations combined).

A brief glance at the real world shows that the quantity, the velocity and the uses of money are changing all the time. However, some economists brush these matters to one side and stick to a simple income-expenditure model when they interpret the real world. A common shortcut is to take expenditures as being determined in naïve Keynesian fashion and to claim 
that the quantity of money then adjusts to the level of expenditures. To quote from Dow again, 'Change in nominal GDP [that is, gross domestic product] determines change in broad money. Money is thus not the driving force in the economy, but rather the residuary determinant (sic) ${ }^{7}{ }^{7}$

But Dow is simply wrong. Banks are forever expanding and contracting their balance sheets for reasons which have nothing whatever to do with the recent or current levels of nominal GDP. For example, when banks lend to customers to finance the purchase of old houses, land and longestablished companies (that is, to finance the purchase of existing assets), they add to the quantity of money, but their activities do not in the first instance impinge on the industrial circulation. They have no immediate and direct effect on national income or expenditure. Nevertheless, agents have to reshuffle their money holdings and portfolios - in a second, third or more round of transactions - so that the extra money is again in balance with their wealth and current expenditure. The vital principle becomes that national income and the value of assets are in equilibrium, and so incomes and expenditure are likely to remain the same period after period, only when the demand to hold money balances is equal to the supply of such balances (that is, the quantity of money) at the end of each and every period, and when the quantity of money is constant. More briefly, national income is in equilibrium only when 'monetary equilibrium' also prevails. After all, it was Keynes himself who said, 'incomes and prices necessarily change until the aggregate of the amounts of money which individuals choose to hold at the new level of incomes and prices ... has come to equality with the amount of money created by the banking system. That . . is the fundamental proposition of monetary theory'. ${ }^{8}$

On this view changes in the quantity of money - particularly big changes in the quantity of money - shatter the cosy equivalence of income and expenditure which is the kernel of naïve Keynesianism. Indeed, a sudden sharp acceleration in the rate of money supply growth might create a severe 'monetary dis-equilibrium', and initiate adjustment processes in which first asset prices and later the prices of goods and services would have to change. ${ }^{9}$ A 25 per cent jump in the quantity of money would - with some technical caveats - increase the equilibrium values of both national income and national wealth also by 25 per cent. One interesting possibility cannot be excluded. It might be that - in the period of transition from the old equilibrium to the new - some asset prices need to rise by more than 25 per cent, in order to stimulate excess demand in goods markets and motivate the required 25 per cent rise in national income. At any rate, any comprehensive account of the determination of national income economists must have a theory of money-holding behaviour and this theory has to recognize that money is only one part of a larger portfolio of assets. 


\section{II}

All this may seem a long way from the 1981 Budget. It is therefore now time to bring the discussion back to the contemporary context by discussing the values of income, money, assets and related variables in Britain at the time. The UK's money GDP in 1980 and 1981 were about $£ 215$ billion and $£ 233$ billion respectively. The gross wealth of the personal sector at the end of 1980 was estimated at $£ 658$ billion, split between $£ 461$ billion of physical assets (mostly houses) and $£ 283$ billion of financial assets, and offset by $£ 86$ billion of debt to leave net wealth at $£ 658$ billion. Total national wealth including public sector and corporate assets - was nearer $£ 1100$ billion. At the end of 1980 the quantity of money, on the very broad M4 measure which included building society deposits, was worth slightly above $£ 130$ billion, while sterling M3 (the subject of the official money targets then in force) was $£ 68.5$ billion. The value of all transactions - including all cheque and other clearings between the banks - in 1980 was over $£ 4000$ billion.

A number of comments need to be made straight away about these numbers. Two features are striking. First, the value of all transactions was a very high multiple of money GDP (or 'national income'). Roughly speaking, total transactions were about 20 times as large as national income. Secondly, wealth was a high multiple of money GDP. To say that wealth was five times national income would be broadly correct, although the precise multiple depends on the valuation conventions adopted. Most wealth was owned by the personal sector, even though some of it was held indirectly via financial products of various kinds. Housing was the personal sector's principal asset.

It is obvious that the national income and expenditure, the central actors in the naive Keynesians' circular flow, took bit parts in the wider drama of total transactions. To repeat, national income was somewhat more than $£ 200$ billion, while total transactions exceeded $£ 4000$ billion. Plainly, the majority of the transactions were not in goods and services, but in assets. In terms of size, the financial circulation dominated the industrial circulation. The preponderance of asset transactions was partly due to the second salient feature, that the value of national wealth was five times that of national income. The value of turnover on the London Stock Exchange in 1980 was $£ 196.3$ billion, not much less than GDP, while the value of turnover in gilt-edged securities was over $£ 150$ billion. In addition, there were transactions in foreign exchange, in unquoted companies and small businesses, in houses, commercial property and land, and in such items as antiques, second-hand cars and personal chattels.

How does this bear on the debate about the 1981 Budget? The 1980 Budget had proposed a Medium-Term Financial Strategy for both the 
budget deficit (defined in terms of the public sector borrowing requirement or PSBR) as a percentage of GDP and money supply growth. Targets for both these variables had been set for the financial years to $1983 / 84$. The target for the 1981/82 PSBR/GDP ratio in the 1980 Budget was 3 per cent of GDP. In practice the PSBR in the closing months of 1980 proved much higher than expected and the projections in early 1981 were that, on unchanged policies, the PSBR/GDP ratio in 1981/82 would be over 5 per cent. The government wanted to restore the credibility of the MTFS. It therefore announced in the 1981 Budget tax increases and other measures which would cut the PSBR/GDP ratio in 1981/82 by about 2 per cent of GDP (that is, about $£ 4$ billion). This tightening of fiscal policy at a time of recession was what provoked the letter to The Times from the 364. For economists who believed in naïve Keynesianism and the incomeexpenditure model, a demand withdrawal of 2 per cent of GDP implied that over the year or so from March 1981 national expenditure and income would be at least 2 per cent lower than would otherwise be the case. (Some of them might appeal to the multiplier concept, also developed in Keynesian textbooks, to say that the adverse impact on demand would be 2 per cent plus something extra because of supposed 'multiplier effects'.)

But hold on. As the past few paragraphs have shown, the total annual value of transactions in Britain at the time of the 1981 Budget was over $£ 4000$ billion. The $£ 4$ billion tax increase might seem quite big relative to national income and expenditure, but it was a fleabite - a mere 0.1 per cent of total transactions. Given that national wealth is about five times national income, the impact of changes in national wealth on expenditure has to be brought into the discussion. As it happened, the 1981 Budget was accompanied by a reduction in interest rates, with the Bank of England's Minimum Lending Rate falling from 14 to 12 per cent. This cut followed an earlier one, from 16 to 14 per cent, on 25 November 1980. The value of the UK housing stock and quoted equity market was rising throughout the period, partly because of rather high money growth and (from the autumn of 1980) the easing of monetary policy. Over the three years to end-1982 the value of the personal sector's money holdings advanced by over $£ 40$ billion and the value of three largest other items in its wealth (dwellings, equity in life assurance and pension funds, and directly owned 'UK ordinary shares') increased by more than $£ 120$ billion and of its net wealth by almost $£ 200$ billion. (See Table 9.1.) These numbers are an order of magnitude larger than the $£ 4$ billion tax increase in the 1981 Budget. Should anyone be surprised that the Budget was not followed by a deepening of 'the depression' or by en erosion of 'the industrial base of our economy' which would 'threaten its social and political stability'? 
Table 9.1 Value of the main items in the UK personal sector's wealth, 1979-82 (£ million)

\begin{tabular}{lrrrr}
\hline & 1979 & 1980 & 1981 & 1982 \\
\hline Notes and coin & 7717 & 8307 & 8837 & 9153 \\
Bank deposits & 36210 & 43188 & 47662 & 51685 \\
Building society deposits & 42442 & 49617 & 56699 & 66993 \\
All monetary assets & 86369 & 101112 & 113198 & 127831 \\
Dwellings & 276600 & 313200 & 323700 & 345900 \\
Equity in life assurance & 37000 & 49000 & 57000 & 75000 \\
$\quad$ pension funds & 31389 & 36482 & 38297 & 45035 \\
UK ordinary shares & 344989 & 398682 & 418997 & 465935 \\
Three leading assets & & & & \\
$\quad$ classes combined & 580529 & 657903 & 696909 & 776754 \\
Net wealth & & & & \\
\hline
\end{tabular}

Source: February 1984 issue of Financial Statistics (London: Her Majesty's Stationery Office), Table S12, p. 140.

With 'exquisite' timing (to use Lawson's word, in $A$ View from No. 11), the recovery in the economy began almost immediately after the letter from the 364 appeared in The Times. Figure 9.1 shows the annualized growth of domestic demand, in real terms, in two-quarter periods from the start of the Conservative government in mid-1979 to the end of 1984. In every twoquarter period from mid-1979 to the first quarter 1981 domestic demand fell in real terms; in every two-quarter period over the five years from Q1 1981 domestic demand rose in real terms (with two minor exceptions). From mid-1979 to Q1 1981 the compound annualized rate of fall in domestic demand was 3.8 per cent; in the five years from Q1 1981 the compound annual rate of increase in domestic demand was 3.3 per cent. The warnings of a deepening of the depression were not just wrong, but hopelessly so.

\section{III}

Of course there is much more to be said about the behaviour of the economy in this period. A naïve Keynesian might ask why - if asset prices were gaining ground in 1980 and 1981 - a recession had occurred at all. While the causes of the 1980 recession are complex, the dominant consideration was plainly the very high level of interest rates. Minimum Lending Rate (then the name for the interest rate on which the Bank of England 


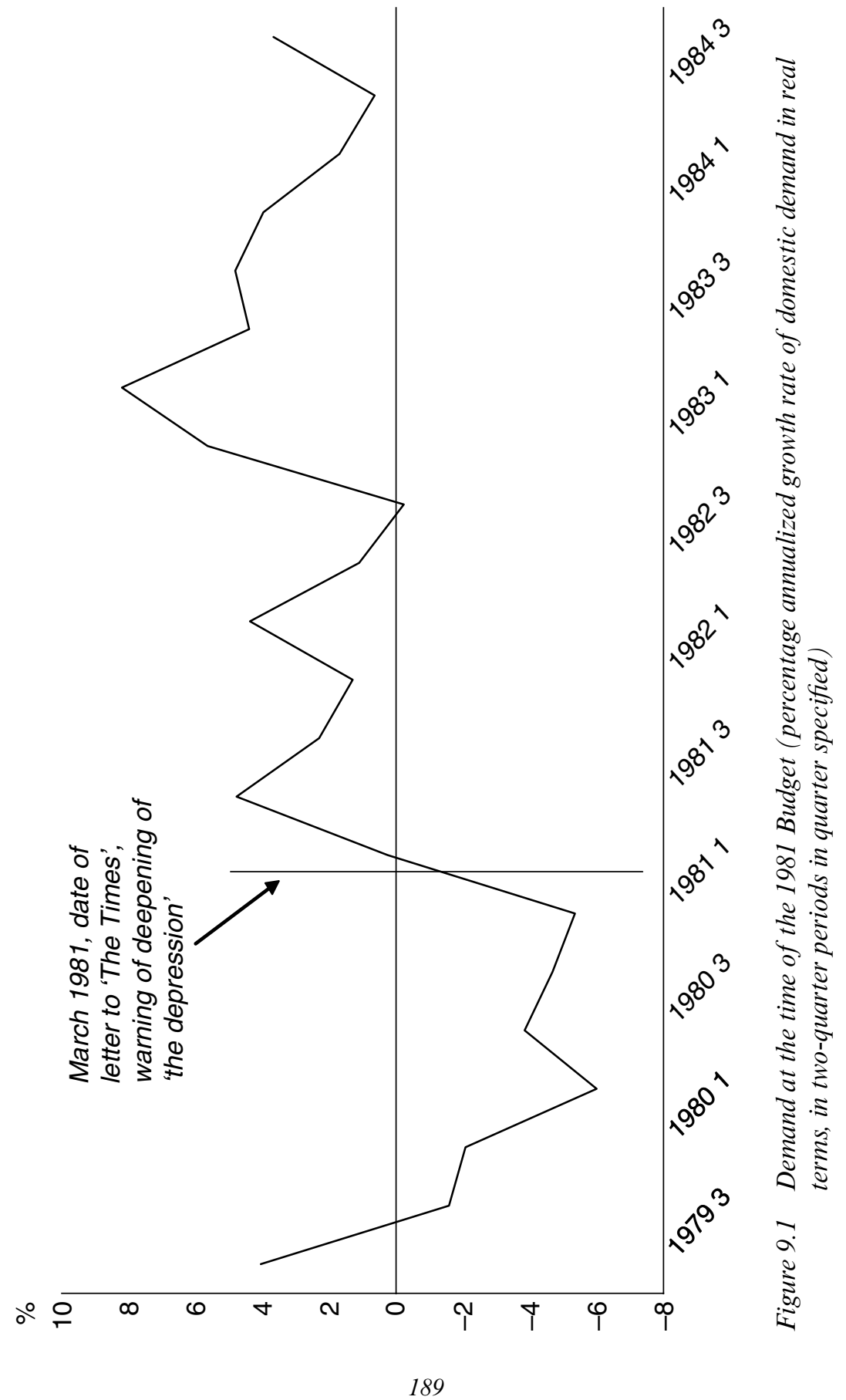


operated) had been raised to 17 per cent on 30 November 1979 and the average level of clearing bank base rate in 1980 was over 16 per cent. While this had discouraged demand by familiar Keynesian mechanisms (such as the discouragement of investment), monetary forces had also been at work. Dear money had caused money supply growth to be lower than would otherwise have been the case, and encouraged people and companies to hold a higher ratio of interest-bearing money balances to their expenditure. Although money supply growth had been higher than targeted, real money balances had in fact been squeezed. The precise strength of these different 'Keynesian' and 'monetary' influences on demand is difficult to disentangle.

(An appendix derives estimates of the change in the cyclically adjusted public sector financial deficit, as a percentage of GDP, and the change in real broad money balances on an annual basis from 1949 to 2004. The change in the PSFD/GDP ratio is usually regarded as a satisfactory summary measure of fiscal policy. The change in real domestic demand was then regressed on the two variables over four periods, the whole period [that is, 1949-2004] and three sub-periods [1949-64, usually regarded as the 'the Keynesian revolution', 1965-80 and 1981-2004]. The resulting equation for fiscal policy over the whole 1949-2004 period was poor, although not totally disastrous, with a $\mathrm{r}^{2}$ of 0.11 and a $\mathrm{t}$ statistic on the regression coefficient of 2.56 , that is, slightly less than the value of three usually thought necessary for a significant relationship. The equation for real broad money was better. It had a $\mathrm{r}^{2}$ of 0.31 and a t statistic on the regression coefficient of 4.98. However, in the 1981-2004 period no relationship whatever obtained between the change in domestic demand and fiscal policy, whereas monetary policy - as measured by the change in real broad money - still seemed to be working. While this exercise is primitive, it suggests that the naïve Keynesian faith in fiscal policy in 1981 was mistaken. By contrast, the role of the 'real balance effect' - routinely dismissed by Keynesians as virtually irrelevant to the determination of demand justifies much more investigation. See the appendix to this essay for more details and see Figure 9.2.)

The author of this essay wrote an article in The Times on 14 July 1983, under the title 'How 364 economists can be wrong - with the figures to prove it'. It argued that the thinking behind the MTFS was 'that the economy had in-built mechanisms which would sooner or later lead to improved business conditions'. It also pointed out that economies had grown, admittedly with cyclical fluctuations, for centuries before 'the invention of fiscal fine-tuning, demand reflation and the rest of the Keynesian toolkit'. One key sentence was that, 'if we are to understand how the economy might recover without government stimulus today, we should 


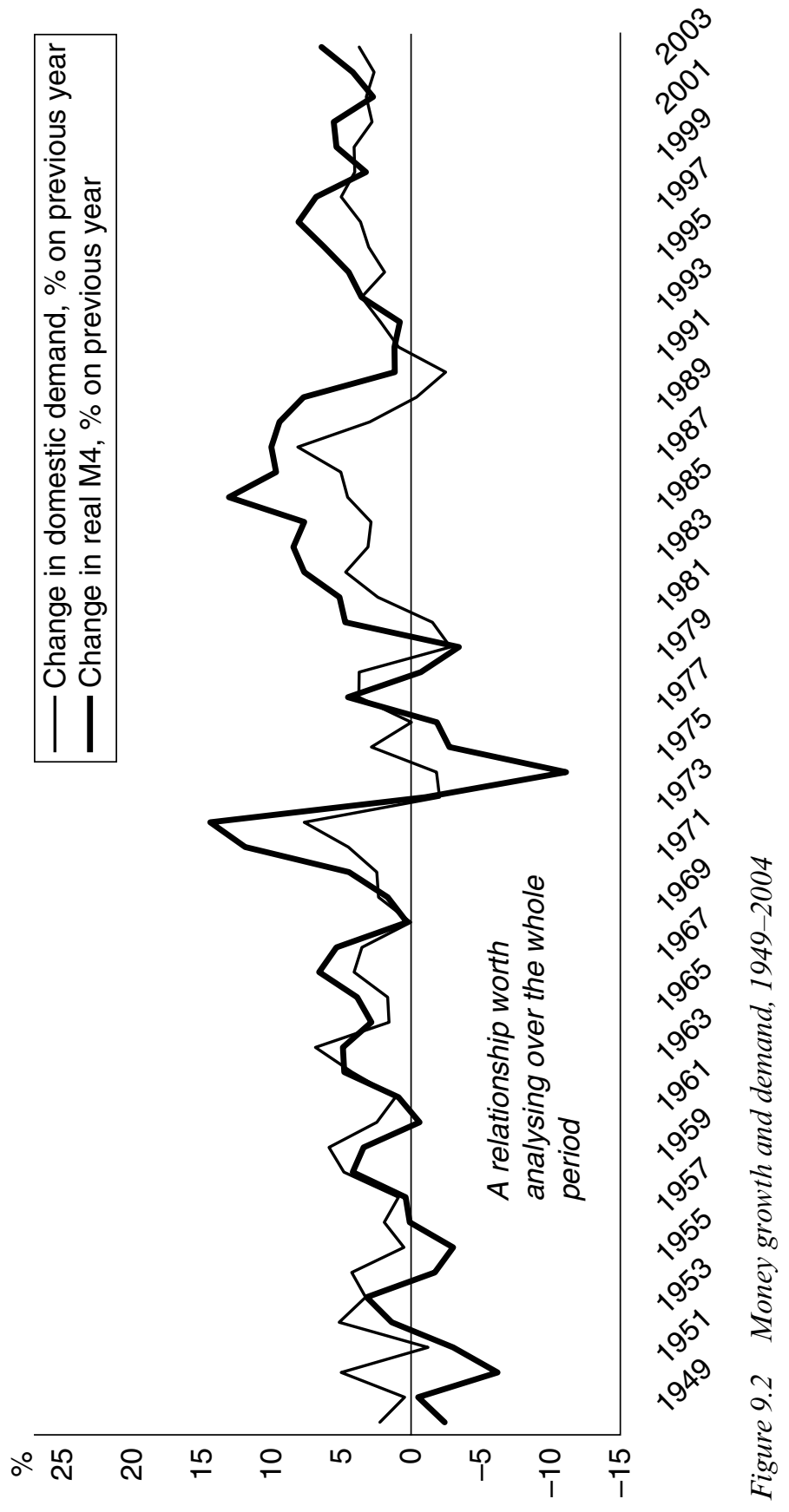


look at wealth and credit'. Particular attention was paid to the housing market and mortgage credit, since 'borrowing for house purchase is the biggest financial transaction most people undertake'. Data in an accompanying table showed that mortgage credit had more than doubled from $£ 6590$ million in 1979 to $£ 13795$ million in 1982.

A reply appeared in the letters column of The Times on 29 July from Frank Hahn, one of the two economics professors at the University of Cambridge who had initiated the original letter criticizing the 1981 Budget. Hahn deserves two cheers because he did at least try to defend the 1981 letter, whereas most of the 364 have clammed up. (The author knows a few of them - with later careers of great public prominence - who would prefer not to be reminded that they signed it.) Its opening paragraph was lively and polemical, and may be recalled over 20 years later,

Suppose 364 doctors stated that there is 'no basis in medical theory or supporting evidence' that a man with an infection will be cured by the administration of toad's liver. Suppose, none the less, that the man is given toad's liver and shows signs of recovery. Mr. Congdon (July 14) wants us to conclude that the doctors were wrong. This is slightly unfair since Mr. Congdon provides a 'theory' of how toad's liver may do good to the patient.

It went on to claim that the recovery in the economy (which Hahn did not dispute) could be explained in 'entirely Keynesian' terms, by the fall in interest rates and its impact on consumer spending. ${ }^{10}$

The trouble here is twofold. First, if Hahn had always believed that a fall in interest rates could rescue the economy, why did he help in organizing the letter from the 364 ? It is uncontroversial both that a decline in interest rates ought to stimulate demand and that the 1981 Budget was intended to facilitate a reduction in interest rates. Presumably Hahn's concern was about relative magnitudes. He thought that the $£ 4$ billion of supposed 'demand withdrawal' announced in the Budget could not be offset by the positive effect on demand of the drop in interest rates and the rise in asset values. If so, he may have shared a characteristic of Cambridge macroeconomic thinking in the immediate post-war decades, that demand is interestinelastic and that policy-makers should instead rely on fiscal measures. ${ }^{11}$ One purpose of the author's article on 14 July 1983 was to show that the housing market was highly responsive to interest rates and that pessimism about the economy's in-built recovery mechanisms was misplaced. ${ }^{12}$

Secondly, and much more fundamentally, Hahn's polemics concealed the deeply unsatisfactory state of Cambridge and indeed British macroeconomics. To simplify greatly but not in a misleading way, part of Keynes's contribution to economic thinking had been to propose a new theory of national income determination. In that theory national income was equal 
to national expenditure and expenditure was a multiple of so-called 'autonomous expenditure' (that is, investment and government spending). Dow's recapitulation of the circular flow of incomes and expenditure in Major Recessions was of course very much in this tradition. But Keynes fully recognized that the new theory was a supplement to an existing theory, 'the monetary theory'. As already explained, when money and assets are introduced into the economy, the equilibrium relationship between them and expenditure has inevitably to be part of the story. Keynes did not intend that the new theory should replace the old theory.

In a celebrated paper written in 1937, as a review article on Keynes's General Theory, Hicks had tried to reconcile the two theories in a model (the so-called IS-LM model) where national income was a multiple of investment and investment was equal to savings (that is, the IS curve was defined), and where national income and the interest rate were at levels which equilibrated the demand for money with the supply (that is, the LM curve was also defined). Full equilibrium, with the determination of both interest rates and national income, was achieved by the intersection of the two curves. But in practice most British economists had found the monetary side of the story complicated and confusing, and sidestepped the difficulties by the sort of procedures adopted in Dow's Major Recessions. Like Dow, they fixed national income from their income-expenditure model and assumed that the quantity of money adjusted passively (or, in the jargon, 'endogenously'). The quantity of money could then have no causal role in the economy. The LM part of the IS-LM model, and the possibility that asset prices and incomes might have to change to keep the demand to hold money (that is, 'liquidity preferences' or L) in line 'the amount of money created by the banking system' (that is, M), was suppressed. What Keynes deemed in The General Theory 'the fundamental proposition of monetary theory' had disappeared from view. ${ }^{13}$

\section{IV}

The message of the letter from the 364 was that British academic economists could not see national income determination in monetary terms. They were angry because the Thatcher government had adopted monetary targets to defeat inflation and subordinated fiscal policy to these targets, and because monetary targets made sense only if their pet theory were wrong and the monetary theory of national income determination were correct. In retrospect, it is clear that the 364 had a poor understanding of the forces determining output, employment and the price level. The LM part of the story mattered then (as it matters now), but the 364 could not 
see the connections between money growth and macroeconomic outcomes. Although policy-making has improved dramatically since the 1970s and 1980s, a fair comment is that British economists are still uncomfortable with monetary analysis. No one knows whether that discomfort will lead through mistaken policy decisions to another boom-bust cycle. But it can be argued that the 1981 letter to The Times was part of a wider assault on money supply targeting which led to the abandonment of broad money targets in 1985 and 1986. The sequel was the disastrous Lawson boom and ERM bust of the 1985-92 period. That boom-bust cycle can therefore be blamed on British economists' weak knowledge of monetary economics; it reflected, in other words, 'a great vacuum in intellectual understanding' and may be characterized as 'the revenge of the 364' on the Thatcher government. ${ }^{14}$

At any rate, the 1981 Budget was the end of naive Keynesianism. It is now over 25 years since British governments renounced the annual adjustment of fiscal policy to manage demand. In that 25-year period fiscal policy has been subordinate either to monetary policy or to rather vague requirements of 'prudence'. In decisions on the size of the budget deficit, governments have respected the aim of keeping public debt under control over a medium-term time frame. The central theme of macroeconomic policymaking today is instead the discretionary adjustment of the short-term interest rate by an independent Bank of England to keep demand growing in such a way that actual output is, as far as possible, equal to trend output (that is, the output gap is zero). Professor Hahn - and as many of the 364 who are still alive and prepared to put their heads above the parapet might regard the disappearance of fiscal fine-tuning and the apotheosis of interest-rate setting as a diet of 'toad's liver'. Someone should tell them that the patient has lapped it up. The British economy has been more stable over the last 15 years than in any previous period of comparable length. Policymakers do not pay all that much attention to fiscal policy in their macroeconomic prognoses, although - depressingly - it is still possible to come across textbooks which proclaim the virtues of fiscal policy and its ability to manage demand. ${ }^{15}$

As foreshadowed by the author's article in The Times in July 1983, the relationship between interest rates and the housing market has become a more central part of macroeconomic analysis than the supposed impact of changes in the budget deficit in adding to or subtracting from the circular flow of income and expenditure. Nowadays the Bank of England is particularly active in research on the housing market. ${ }^{16}$ Much attention is paid to the rate of house price inflation (or deflation), because the change in the price of this asset is thought to have a major influence on consumer spending. But houses are only one asset class. In truth the level and rate of 
change of all asset prices matter. A key point has now to be reiterated: any plausible theory of money-holding behaviour has to recognize that money is only one part of a larger portfolio of assets. If a number of conditions are met (and over long runs they are met, more or less, in most economies), a 1 per cent increase in the annual rate of money supply growth is associated with a 1 per cent increase in the equilibrium annual growth rates of both nominal national income and the value of national wealth. Moreover, national wealth is typically a high multiple of national income. It follows that a sudden acceleration in the rate of money supply growth (of the kind seen in the early phases of the two great boom-bust cycles of the early 1970s and late 1980s) leads to outbreaks of asset price inflation. Big leaps in asset prices cause people and companies to sell assets, and to buy more goods and services, disrupting the smooth flows of incomes and expenditure hypothesized in the naive Keynesian stories. Because the value of all assets combined is so much higher than the value of national income, the circular income-expenditure flow can become a thoroughly misleading way of thinking about the determination of economic activity.

The macroeconomic effects of the $£ 4$ billion tax increase in the 1981 Budget were smothered by the much larger and more powerful macroeconomic effects of changes in monetary policy. No doubt the naïve Keynesian would complain that this is to compare apples and pears, as hypothetical changes in asset values and their impact on expenditure are a long way from the readily quantified and easily forecast impact of budgetary measures. But that would be to duck the main question. As the sequel to the 1981 Budget showed, the naïve Keynesians are kidding themselves if they think either that the economy is adequately described by the income-expenditure model or that the impact of budgetary measures on the economy is easy to forecast. ${ }^{17}$ (As the author argued in a series of articles in The Times in the mid-1970s on 'crowding-out', the effect of such measures depends heavily on how they are financed and, specifically, on whether they lead to extra money creation. ${ }^{18}$ One of these articles is republished here as Essay 8.) Macroeconomics must embrace monetary economics, and integrate the ideas of monetary and portfolio equilibria (and disequilibria) in the theory of national income determination if it is come closer to reality.

It is ironic that the two instigators of the 1981 letter thought themselves to be protecting the 'Keynesian' position in British policy-making and to be attacking 'the monetarists'. ${ }^{19}$ As this essay has shown, Keynes's writings or at any rate his book-length writings - are replete with references to banks, deposits, portfolios, bond prices and such like. No one can say whether he would have approved of the 1981 letter, but it is pretty definite that he would not have based a macroeconomic forecast purely on fiscal variables. The concepts of the industrial and financial circulations were proposed in the 
Treatise in 1930. They are building-blocks in a more complete and powerful theory of national income determination than the simplistic incomeexpenditure notions advanced in the 'Paying for the war' articles of November 1939. If the Keynesians had paid more attention to what Keynes had said in his great works rather than in his journalism, and if they had been rather more sophisticated in their comments on money and wealth, they might not have been so embarrassingly wrong about the 1981 Budget.

\section{NOTES}

1. The articles are reproduced on pp. 41-51 of D. Moggridge (ed.), The Collected Writings of John Maynard Keynes, vol. XXII, Activities 1939-45: Internal War Finance (London: Macmillan, for the Royal Economic Society, 1978).

2. R.J. Ball, Money and Employment (London: Macmillan, 1982), p. 29.

3. J.C.R. (Christopher) Dow, Major Recessions: Britain and the World 1920-95 (Oxford: Oxford University Press, 1998), p. 38. Dow has a high reputation in some circles. Peter Jay, the former economics editor of the BBC, has referred to 'the learned Dow' and described Major Recessions as 'magisterial'. (P. Jay, The Wealth of Man [New York: Public Affairs, 2000], p. 238.)

4. The other recognized source of demand injections and withdrawals was the rest of the world, via the balance of payments.

5. As usual in discussions of these concepts, the question of the timing of the receipt of 'income' and the disbursal of 'expenditure' is left a little vague. The income-expenditure story is most plausible if people have nothing (that is, neither money nor assets) at the end of a period, and receive their income at the beginning of a period and have spent it all by the same period's end. In other words, the story is easiest to tell about an economy without private property of any kind.

6. D. Moggridge and E. Johnson (eds), Collected Writings of Keynes, vol. V, A Treatise on Money: 1. The Pure Theory of Money (Macmillan, 1971, 1st edition 1930), p. 217.

7. Dow, Major Recessions, p. 39. Given the context, Dow must have meant 'determinand', not 'determinant'.

8. Moggridge and Johnson (eds), Collected Writings of Keynes, vol. VII, The General Theory, pp. 84-5. Note that - in this quotation - the word 'prices' referred to the prices of securities, not of goods and services.

9. These processes are discussed in more detail in the author's Money and Asset Prices in Boom and Bust (London: Institute of Economic Affairs, 2005). It seems that - after a big change in the amount of money - asset prices change with a shorter lag and by larger percentages than the prices of goods and services. The explanation for this undoubted pattern is important to the analysis of real-world business cycles.

10. Hahn made an attempt at self-justification by claiming that 'the monetarists' deny that an injection of newly printed money can boost demand because inflation expectations would deteriorate and 'nothing "real" will be changed'. But this is to equate 'monetarism' with the New Classical Economics of Lucas, Barro, Sargent and others. It is now widely recognized that these are distinct schools of economics. (See, for example, K.D. Hoover, 'Two types of monetarism', Journal of Economic Literature, vol. 22, 1984, pp. 58-76.) Hahn's letter ended with a sneer. 'Mr. Congdon's understanding of either side of the argument [by which he presumably mean either the Keynesian or monetarist side] seems very insecure.'

11. 'Elasticity pessimism', that is, a belief that behaviour did not respond to price signals, was common among British economists in the first 20 or 30 years after the Second World War. Investment was thought to be unresponsive to interest rates, while exports and 
imports were held to be impervious to changes in the exchange rate. Leijonhufvud has outlined one 'familiar type of argument' as the claim that, 'The interest-elasticity of investment is for various reasons quite low. Hence, monetary policy is not a very useful stabilization instrument'. Hahn and the 364 may have been thinking on these lines. Leijonhufvud says that 'the dogma' of the interest-inelasticity of investment originated in Oxford, with surveys of businessmen carried out in 1938, not in Cambridge. (A. Leijonhufvud, On Keynesian Economics and the Economics of Keynes [New York: Oxford University Press, 1968], p. 405.) But it was still widely held in Cambridge and other British universities in the 1970s and even in the 1980s.

12. Before the July 1983 article in The Times the author had proposed the concept of 'mortgage equity withdrawal' in a joint paper with Paul Turnbull. (See 'Introducing the concept of "equity withdrawal", in T. Congdon, Reflections on Monetarism [Aldershot, UK and Brookfield, US: Edward Elgar, for the Institute of Economic Affairs, 1992], pp. 274-87, based on a paper of 4 June 1982 for the stockbroking firm of L. Messel \& Co., 'The coming boom in housing credit'.) Dozens of articles have subsequently been written about 'mortgage equity withdrawal' and its influence on personal expenditure, and the Bank of England regularly prepares estimates of its size. To economists spoon fed at university on the circular flow of income and the income-expenditure model (in which, as explained, assets do not affect expenditure), mortgage equity withdrawal was a striking idea. It showed how people whose only significant asset was a house (which is of course rather illiquid) could tap into the equity (often boosted in the Britain of the early 1980 s by house price inflation) by borrowing.

13. Note that monetary equilibrium could refer to:

i. the equivalence of the demand for base money with the supply of base money, or

ii. the equivalence of the demand for narrow money with the supply of narrow money, or

iii. the equivalence of the demand for a broad money measure with the supply of broad money, or

iv. the simultaneous equivalence of the demand for all money measures with the supply of all such measures.

The 'which aggregate?' debate will not go away. The chaos in the subject helps to explain why so many economists have dropped money from their analytical purview.

14. Congdon, Reflections, p. 252. The author first used the phrases 'vacuum in intellectual understanding' and 'the revenge of the 364' in an inaugural lecture to Cardiff Business School in November 1990, which now forms the bulk of Essay 3 in this volume.

15. For example, the textbook Principles of Macroeconomics (New York: Irwin/McGrawHill, 2nd edition, 2003) by Ben Bernanke and Robert Frank contains an account of national income determination and the efficacy of fiscal action which could have been lifted, in its entirety, from a similar textbook of the 1950s. Bernanke was professor of economics at Princeton University, a university widely regarded as in the vanguard of macroeconomic thought, when the textbook was published. Now - as chairman of board of governors of the USA's Federal Reserve - he holds the most important position in monetary policy-making in the world.

16. In the 1970s the Bank of England's Quarterly Bulletin did not include a single article on the housing market. In the three years to the summer of 2005 the Quarterly Bulletin carried seven articles and two speeches by the members of the Monetary Policy Committee which related specifically to the housing market.

17. But the majority of British economists do not think that the income-expenditure model has been discredited by the sequel to the 1981 Budget. For example, the Bank of England's macro-econometric model remains a large-scale elaboration of an incomeexpenditure model in which money is, to use the phrase that Dow presumably intended, a 'residuary determinand'. See The Bank of England Quarterly Model (London: Bank of England, 2005), passim.

18. T. Congdon 'The futility of deficit financing as a cure for recession', The Times, 23 October 1975. Some economists had seen in the late 1970s that the impact of fiscal 
policy on the economy was not independent of how budget deficits were financed. According to Ball in a book advocating 'practical monetarism', 'if the money supply is chosen as a policy target, the stance of fiscal policy must be consistent with it. [Fiscal and monetary policies] cannot in practice be operated independently in the medium term. For this reason academic debates about the "pure" effects of fiscal policy lose much of their raison d' etre.' (Ball, Money and Employment, p. 184.) Ball worked closely with T. Burns at the London Business School in the late 1960s and early 1970s, and Burns became the government's Chief Economic Adviser in 1980.

19. The two instigators were Professor Robert Neild and Professor Frank Hahn. Neild's subsequent interests were in peace studies and corruption in public life. (He has also written a history of the oyster in England and France.) As far as the author can determine, he dropped macroeconomics at some point in the 1980s. Hahn's position is more interesting and, in the author's opinion, more puzzling. He has written numerous academic papers on money (and money-related issues) in general equilibrium theory, brought together in Frank Hahn, Equilibrium and Macroeconomics (Oxford: Basil Blackwell, 1984). Most of the papers in the 1984 book were concerned with rarefied topics, such as the existence, stability and optimality of differently specified general equilibria. However, four of the papers (numbered 12 to 15 ) were more or less directly polemical exercises whose target was 'monetarism' or, at any rate, what Hahn took to be 'monetarism'. They cannot be summarized here for reasons of space, but a salient feature of all the papers was the lack of references to real-world institutions, behaviours and magnitudes. Following Keynes, the author has argued - in the current essay and elsewhere that a discussion of the determination of national income must be, to a large extent, a discussion of the role of money in portfolios. In a 1980 paper on 'Monetarism and economic theory' Hahn cited a number of recondite papers before seeing in 'recent macroliterature' two elements 'that Keynesians have for long ignored'. One was the portfolio consequences of budget deficits and the other 'wealth effects'. (Equilibrium and Macroeconomics, p. 299) Given that, might one ask why Hahn should have been so sarcastic about the author's 1983 article in The Times, and its concern with mortgage credit, houses and wealth? And might one also ask whether he really believes (as apparently he did in 1980 and perhaps as he continued to do when he orchestrated the 1981 letter to The Times) that the government should make 'the rate of change of the money stock proportional to the difference between actual unemployment and half a million unemployed' (Equilibrium and Macroeconomics, p. 305)? Is that the sort of policy which - on a considered analysis - would have led to the macroeconomic stability the UK has enjoyed since 1992 ? 


\section{STATISTICAL APPENDIX: DOES NAÏVE FISCALISM OR NAÏVE MONETARISM FIT THE UK DATA BETTER?}

Doubts have been raised about the validity of the monetary theory of national income determination, with some of the sceptics adopting highpowered econometrics to make their point. In 1983 Hendry and Ericsson published a well-known critique of the methodology used in Friedman and Schwartz's Monetary Trends in the United States and the United Kingdom. ${ }^{1}$ Relatively little work has been directed at assessing the empirical validity of the proposition that changes in domestic demand are heavily, or perhaps even predominantly, influenced by changes in the budget deficit (which might be called 'the fiscalist [or naïve Keynesian] theory of national income determination'). The purpose of this appendix is to compare simple formulations of the fiscal and monetary theories of national income determination. In view of British economists' inclination to downplay or even to dismiss the monetary theory (on the grounds that 'it does not stand up to the facts'), and then to advocate changes in the budget deficit as an appropriate macroeconomic therapy, an exercise on these lines is needed. Series were obtained over the 1948-2004 period for

1. The cyclically adjusted ratio of the public sector financial deficit to GDP, and hence for the change in the ratio from 1949,

2. The change in real broad money, using the M4 measure of money adjusted by the increase in the deflator for GDP at market prices. (The M4 data after 1964 were taken from the official Office for National Statistics website. The M4 data before 1964 used a series prepared at Lombard Street Research, which drew on the data given in F. Capie and A. Webber, A Monetary History of the United Kingdom, 1870-1982, vol. 1. (London: Allen and Unwin, 1985).

3. The change in real domestic demand, where the deflator for GDP at market prices was again used to obtain the real-terms numbers.

The cyclical adjustment to the PSFD data was conducted in the same way as in the author's paper 'Did Britain have a Keynesian revolution? Fiscal policy since 1941', pp. 84-115, in J. Maloney (ed.), Debt and Deficits (Cheltenham, UK and Lyme, USA: Edward Elgar, 1998), which is reprinted in this collection as Essay 4. (For the years 1963/64 to 1986/87 the author's numbers for the cyclically adjusted PSFD/GDP ratio are virtually identical to those given in HM Treasury's Occasional Paper No. 4 on Public Finances and the Cycle, published in September 1995.) The change in the 
cyclically adjusted public sector financial deficit is usually accepted as a satisfactory summary measure of fiscal policy. (The data are available from timcongdon@btinternet.com.)

The change in real domestic demand was regressed against, first, the change in the cyclically adjusted PSFD/GDP ratio (to test a naïve fiscalist hypothesis) and, secondly, the change in real M4 (to test a naïve monetarist hypothesis) for four periods, 1949-2004 as a whole, 1949-64 (that is, the 'Keynesian revolution', 1965-80 (the period when the Keynesian dominance in policy thinking was being eroded) and 1981-2004 (the period when medium-term fiscal rules were adopted, initially because of 'monetarism', but later because of Mr Gordon Brown's 'prudence'). The results are given in Box 9.1.

\section{BOX 9.1 NAÏVE FISCALISM VS. NAÏVE MONETARISM}

\section{The whole 1949-2004 period}

Naïve fiscalism

Change in real domestic demand (\% p.a.) $=2.61+0.56$ Change in PSFD/GDP ratio (\% of GDP, in year in question)

$\mathrm{R}^{2}=0.11$

t statistic on regression coefficient $=2.56$

Naïve monetarism

Change in real domestic demand (\% p.a. $)=1.74+0.28$ Change in real M4 (\% p.a.)

$\mathrm{R}^{2}=0.31$

t statistic on regression coefficient $=4.98$

2. The 1949-1964 sub-period ('the Keynesian revolution')

Change in real domestic demand $(\%$ p.a. $)=2.68+0.73$ Change in PSFD/GDP ratio (\% of GDP)

$\mathrm{R}^{2}=0.19$

t statistic on regression coefficient $=1.82$

Change in real domestic demand $(\%$ p.a. $)=2.87+0.34$ Change in real M4 (\% p.a.)

$\mathrm{R}^{2}=0.23$

$\mathrm{t}$ statistic on regression coefficient $=2.03$ 


\section{The $1965-80$ sub-period (the breakdown of the Keynesian consensus)}

Change in real domestic demand (\% p.a. $)=1.96+0.98$ Change in PSFD/GDP ratio (\% of GDP)

$\mathrm{R}^{2}=0.35$

t statistic on regression coefficient $=2.72$

Change in real domestic demand (\% p.a.) $=1.16+0.37$ Change in real M4 (\% p.a.)

$\mathrm{R}^{2}=0.66$

t statistic on regression coefficient $=5.20$

\section{The 1981-2004 sub-period (the period of medium-term fiscal rules)}

Change in real domestic demand (\% p.a.) $=2.92-0.06$ Change in PSFD/GDP ratio (\% of GDP)

$\mathrm{R}^{2}=0.001$

t statistic on regression coefficient $=-0.16$

Change in real domestic demand $(\%$ p.a. $)=0.64+0.38$ Change in real M4 (\% p.a.)

$\mathrm{R}^{2}=0.28$

t statistic on regression coefficient $=2.95$

The econometrics in Box 9.1 are primitive, but three comments seem in order. The first is that naïve monetarism works better than naïve fiscalism over both the whole period, and in each of the three sub-periods. (See Figure 9.2 comparing the changes in real M4 and real domestic demand over the whole period.) However, naïve fiscalism was only slightly worse than naïve monetarism in the first sub-period (the period of 'the Keynesian revolution'). The second is that in the final sub-period, when medium-term fiscal rules prevailed, the relationship between changes in the budget deficit and domestic demand disappeared. The results of the naïve fiscalist equation in the 1981-2004 sub-period are atrocious. (See Figure 9.3, with its obvious absence of a relationship. The $\mathrm{r}^{2}$ is virtually nothing, and the regression coefficient has the wrong sign and is insignificant.) It is not going too far to say that - in these years - naïve Keynesianism was invalid, while the standard prescription of its supporters ('fiscal reflation will boost employment') was bunk. The third is that the 364 were not entirely silly to believe in 1981 that a reduction in the budget deficit would be deflationary. Although the relationship between the 


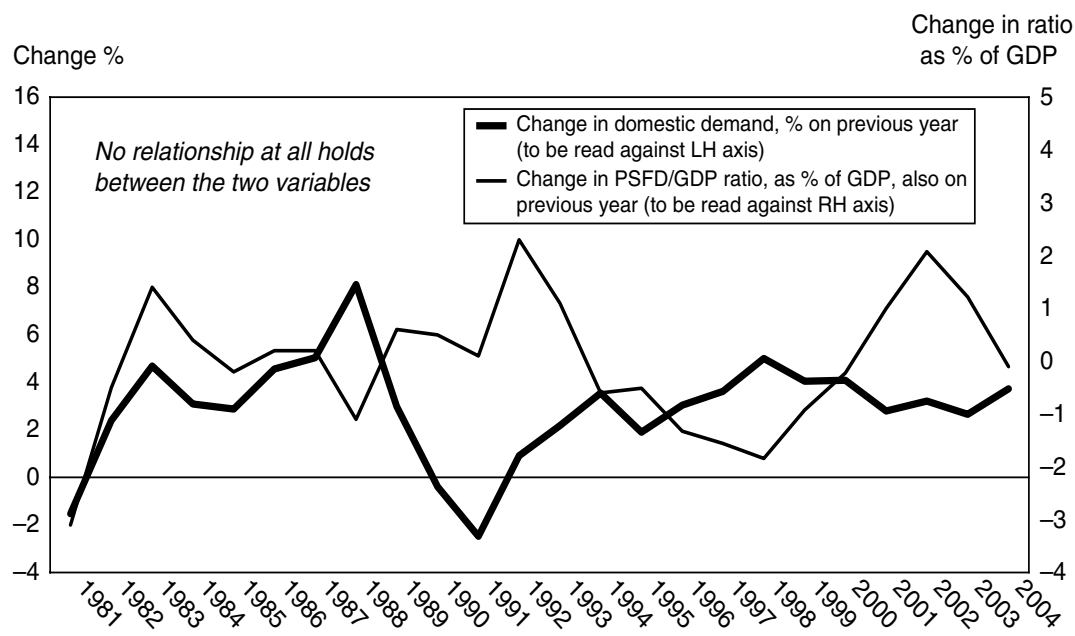

Figure 9.3 Fiscal policy and demand, 1981-2004 ('the period of mediumterm fiscal rules')

changes in the cyclically adjusted budget deficit and domestic demand had been worse than that between changes in real M4 and domestic demand in the preceding 15 years, the naïve fiscalist hypothesis had not done all that badly in the second sub-period. Indeed, by the careful selection of years one period of 21 years (1953 to 1973 inclusive) could be found with an impressively strong relationship between fiscal policy and demand outcomes. (See Figure 9.4.)

It was only in the final 25 years of the post-war period that - on the analysis here - a naïve Keynesian view of national income determination became indefensible. The extremely poor quality of the fiscal equation in the final sub-period raises the question, 'was its better performance in the 1949-64 and 1965-80 sub-periods, and particularly in the 1953-73 subperiod, really because fiscal policy by itself was quite powerful or was it rather because fiscal policy influenced money supply growth and monetary policy was the relevant, strong influence on demand?'. To answer these questions, the author regressed the rate of real M4 growth on both the level and the change in the PSFD/GDP ratio over the whole 1949-2004 period, and the 1949-64 and 1965-80 sub-periods, and was unable to find a relationship between the variables that met standard criteria of statistical significance. Much more work should be done, but it seems the apparent conclusion cannot be denied. To the extent that fiscal policy was effective between 1949 and 1980, it did not work largely though monetary policy and 


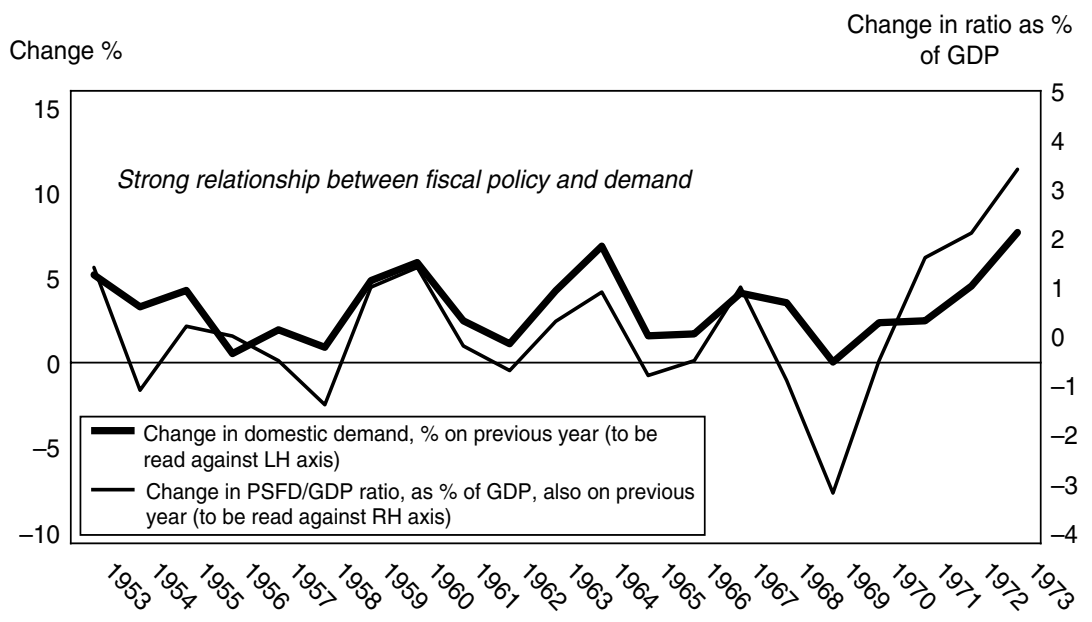

Figure 9.4 Fiscal policy and demand, 1953-73 ('the heyday of Keynesianism')

had some independent effect on the economy. This may solace those (presumably most of the 364) who claim that fiscal policy mattered in these years, even though fiscal policy did not matter after 1980 and monetary policy has always mattered more.

However, a little more investigation raises more questions. The 1953 to 1973 sub-period - the best period for the Keynesian hypothesis - needs to be looked at more carefully. To repeat, fiscal policy ostensibly had a strong effect on domestic demand. (In the equation regressing the change in domestic demand on the change in the PSFD/GDP ratio, the $\mathrm{r}^{2}$ was 0.62 and the $t$ statistic on the regression coefficient was 5.57. The regression coefficient was remarkably close to unity, at 1.15 . In other words, if the Chancellor of the Exchequer were to increase the budget deficit by $£ 500$ million over the next fiscal year, he could be expected to increase domestic demand by slightly more than $£ 600$ million, just as the textbooks said.) Further, in this sub-period naïve Keynesianism worked better than naïve monetarism. (In the equation regressing the change in domestic demand on the rate of real M4 growth, the $\mathrm{r}^{2}$ was 0.41 and the $\mathrm{t}$ statistic on the regression coefficient was 3.63.) Given that this was how macroeconomic policy operated over such an extended period, were not the Keynesians justified in the mid-1970s in believing in the effectiveness of fiscal policy and in the superiority of fiscal over monetary policy? The answer depends on how one views the relationship between fiscal and monetary policy in those years. When the author regressed the rate of real M4 growth on the level and the 
change in the PSFD/GDP ratio over the 1953-73 period, the equation with the change in the PSFD/GDP ratio was much better than in other subperiods and - exceptionally - it was quite good in its own terms. (The $\mathrm{r}^{2}$ was 0.43 and the $t$ statistic on the regression coefficient was 3.77.) This leaves open the possibility that fiscal policy 'worked' between 1953 and 1973, because changes in fiscal policy were accompanied by changes in money supply growth which operated in the same direction and had powerful impacts on demand in their own right. Fiscal policy 'mattered' largely via a monetary channel, because the budget deficit affected the rate of the growth of the quantity of money.

In his celebrated attack on 'the new monetarism' in the July 1970 issue of Lloyds Bank Review, Kaldor scorned the role of monetary policy by claiming that changes in money supply growth could be 'explained' by fiscal policy. In his words: 'I am convinced that the short-run variations in the "money supply" - in other words, the variation relative to trend - are very largely explained by the variation in the public sector's borrowing requirement'. He amplified the point in a footnote which read:

In fact, a simple regression equation of the annual change of the money supply on the public sector borrowing requirement for the years 1954-68 shows that the money supply increased almost exactly $£$ for $£$ with every $£ 1$ increase in the public sector deficit, with $\mathrm{t}=6.1$ and $\mathrm{R}^{2}=0.740$, or, in fashionable language, 74 per cent of the variation in the money supply is explained by the deficit of the public sector alone. ${ }^{2}$

The results of the regression reported in Kaldor's footnote are surprising, since the PSBR was not introduced as an official statistic until 1963 and (unless he had access to internal Treasury estimates, which is possible) no such regression could have been carried out for earlier years. The author has tried to replicate Kaldor's result by regressing the change in 'the money supply' (that is, the sum of notes and coin in circulation and clearing bank deposits) on the public sector financial deficit, for which (to repeat) data are available back to 1948. The equation was markedly worse than the one reported by Kaldor (with a regression coefficient of 0.48 , a $\mathrm{r}^{2}$ of 0.38 and a $\mathrm{t}$ statistic of 2.81), but it was not rubbish. It is indeed plausible that - in the 1950s and 1960s, when bank lending to the private sector was officially restricted for much of the time - a major influence on the growth of banks' balance sheets was the increase in their holdings of public sector debt. Fiscal and debt management policies did affect money supply growth, as most economists thought at the time (and despite the rather conflicting results mentioned in earlier paragraphs).

However, this does not mean - as Kaldor seems to have implied - that in all circumstances fiscal policy dominated monetary policy and that mon- 
etary policy by itself was unimportant. In the 1980s and 1990s, after the removal of credit restrictions, bank lending to the private sector became by far the largest credit counterpart of M4 growth, and the change in money and the budget deficit were no longer correlated. But - as this appendix has shown - the influence of money on demand remained identifiable, whereas the influence of fiscal policy on demand vanished.

In retrospect it is clear that Kaldor went too far in his statement about the link between the budget deficit and money growth. ${ }^{3}$ However, he did at least recognize that fiscal variables, and not monetary variables alone, needed to be cited as evidence in the debate. British Keynesians have later been much too ready to debunk monetary aggregates. The same standards of proof need to be applied to both monetary and fiscal variables.

\section{Notes}

1. D. Hendry and N.R. Ericsson, 'Assertion without empirical basis: an econometric appraisal of Monetary Trends in the United States and United Kingdom, by Milton Friedman and Anna Schwartz', Bank of England Panel of Economic Consultants, Monetary Trends in the United Kingdom, panel paper no. 22, October 1983, pp. 45-101.

2. N. Kaldor, 'The new monetarism', Lloyds Bank Review, July 1970, pp. 1-17, reprinted on pp. 261-78 of A. Walters (ed.), Money and Banking (Harmondsworth: Penguin Books, 1973). See, in particular, p. 277. In the late 1970s Budd and Burns also argued that the fiscal position had a strong medium-term influence on the rate of monetary growth. See A.P. Budd and T. Burns, 'The relationship between fiscal and monetary policy in the LBS model', Discussion Paper no. 51 (Econometric Forecasting Unit: London Business School, June 1978).

3. The breakdown of 'Kaldor's rule' was noted in J.H.B. Tew, 'Monetary policy', in F.T. Blackaby (ed.), British Economic Policy 1960-74 (Cambridge: Cambridge University Press, 1978), ch. 5, pp. 218-303. See, particularly, pp. 277-8. Ironically, for those concerned that excessive money supply growth would lead to inflation, Kaldor's rule justified official action to constrain the budget deficit, as incorporated in the Conservatives' Medium-Term Financial Strategy from 1980. 